\title{
Jäsenistö arvioi Sosiaalilääketieteen yhdistyksen toimintaa
}

\author{
LAURA PÄÄKKÖ, PEIJA HAARAMO \& MIKA GISSLER
}

Sosiaalilääketieteen yhdistyksen perustamisesta on tänä vuonna kulunut 50 vuotta. Yhdistys perustettiin vuonna 1968 poikkitieteelliseksi foorumiksi eri alojen välille, ja kyselyn perusteella se näyttää edelleen tuovan yhteen erityisesti yhteiskuntatieteiden, lääketieteen ja terveydenhuoltoalan tutkijoita ja muita ammattilaisia. Yhdistyksen hallitus yhdessä Sosiaalilääketieteellisen aikakauslehden toimituksen kanssa toteutti juhlavuoden kunniaksi kyselyn, jossa kartoitettiin jäsenten tyytyväisyyttä yhdistyksen toimintaan ja tiedottamiseen sekä Sosiaalilääketieteellisen aikakauslehden sisältöihin, materiaalien saatavuuteen ja uuden toimitusjärjestelmän käytettävyyteen. Kyselyn toteuttamiseen ja raportointiin saatiin rahoitusta Tiedekustantajien liitolta, ja työ toteutettiin Tampereen yliopiston tukemana korkeakouluharjoitteluna.

Yhdistyksen hallituksen nimeämä työryhmä osallistui kyselyn luomiseen ja vastasi tiedonkeruusta keväällä 2018. Kyselyssä oli 40 kysymystä, ja se toimitettiin yhdistyksen kaikille jäsenille toukokuun alussa. Jäsenkysely toteutettiin Webropol -ohjelmistolla, ja se toimitettiin jäsenille sähköpostin linkkinä, Internet-linkkinä tai postitse kirjeenä $(n=474)$. Kyselyyn saatiin 104 vastausta, joista 93 joko sähköpostilinkin tai avoimen nettilinkin kautta ja 11 paperilla. Vastausprosentti oli 21,9\%. Tiedot kerättiin nimettöminä. Kyselyssä, kyselyn raportoinnissa ja aineistojen käsittelyssä noudatettiin ehdotonta luottamuksellisuutta ja hyviä tieteellisiä käytäntöjä.

Kyselyyn vastasi jäseniä eri puolelta Suomea ja kaikista ikäryhmistä. Osallistumisaktiivisuus oli ikäryhmittäin melko tasaista (16-23\%, yhteensä $\mathrm{n}=102$ ) kaikissa muissa vastaajaluokissa, lukuun ottamatta alle 30-vuotiaita, joiden osuus vastaajista oli vain $2 \%$. Aktiivisimpia kyselyyn vastaajia olivat 2010-luvulla liittyneet uudet jä- senet (43\% kysymykseen vastanneista), mutta kysely tavoitti vastaajia kaikilta yhdistyksen vuosikymmeniltä 1960-luvulla liittyneistä tähän vuosikymmeneen asti.

Suurin osa eli $60 \%$ vastaajista asui Uudellamaalla. Yhdistyksen jäsenet ovat kyselyn perusteella poikkitieteellinen ryhmä eri alojen asiantuntijoita (kuvio 1). Suurin osa vastaajista oli kouluttautunut joko terveydenhuollon (29\%),yhteiskuntatieteiden $(28 \%)$ tai lääketieteen $(23 \%)$ alalle. Vastaajista $47 \%$ luokitteli työnsä tutkimus- tai kehittämistyöksi. Osa vastaajista määritteli työnsä useampaan kuin yhteen luokkaan. Eläkkeellä oli $14 \%$, opetustyössä $13 \%$ ja hallinnollisessa työssä 10 \% vastaajista. Suurin osa vastaajista työskenteli julkisella sektorilla: valtiolla $(20 \%)$, yliopistolla $(20 \%)$ tai kunnalla (14\%). Vastaajista $16 \%$ ilmoitti työskentelevänsä jossain luokittelujen ulkopuolisessa organisaatiossa, kuten omassa yrityksessä, järjestöissä, kansainvälisissä tehtävissä, apurahoitteisissa projekteissa tai keikkaluontoisissa vaihtelevissa töissä.

Kyselyssä selvitettiin yhdistyksen jäsenten tyytyväisyyttä yhdistyksen toimintaan ylipäätään, yhdistyksen tapahtumiin, viestintään, jaosten toimintaan ja jäsenmaksuihin. Vastaajista $66 \%$ oli yleisellä tasolla tyytyväisiä tai erittäin tyytyväisiä yhdistyksen toimintaan. Tyytyväisyyttä kysyttiin Likert-asteikolla 1-5, missä neutraalin arvosanan 3 antoi noin $30 \%$ vastaajista. Erittäin tyytymättömiä vastaajia ei ollut yhtäkään, mutta tyytymättömiä oli $4 \%$ vastaajista. Vastaajista $92 \%$ ilmoitti hyötyneensä jäsenyydestä jollain tavalla. Avovastausten perusteluissa tärkeiksi mainittiin yhdistyksen julkaisutoiminta, verkostot ja yhdistyksen jakama informaatio. Lisäksi kansainväliset yhteydet, erityisesti European Public Health Association (EUPHA) ja matkastipendit koettiin yhdistyksen jäseniä palvelevaksi toiminnaksi. 


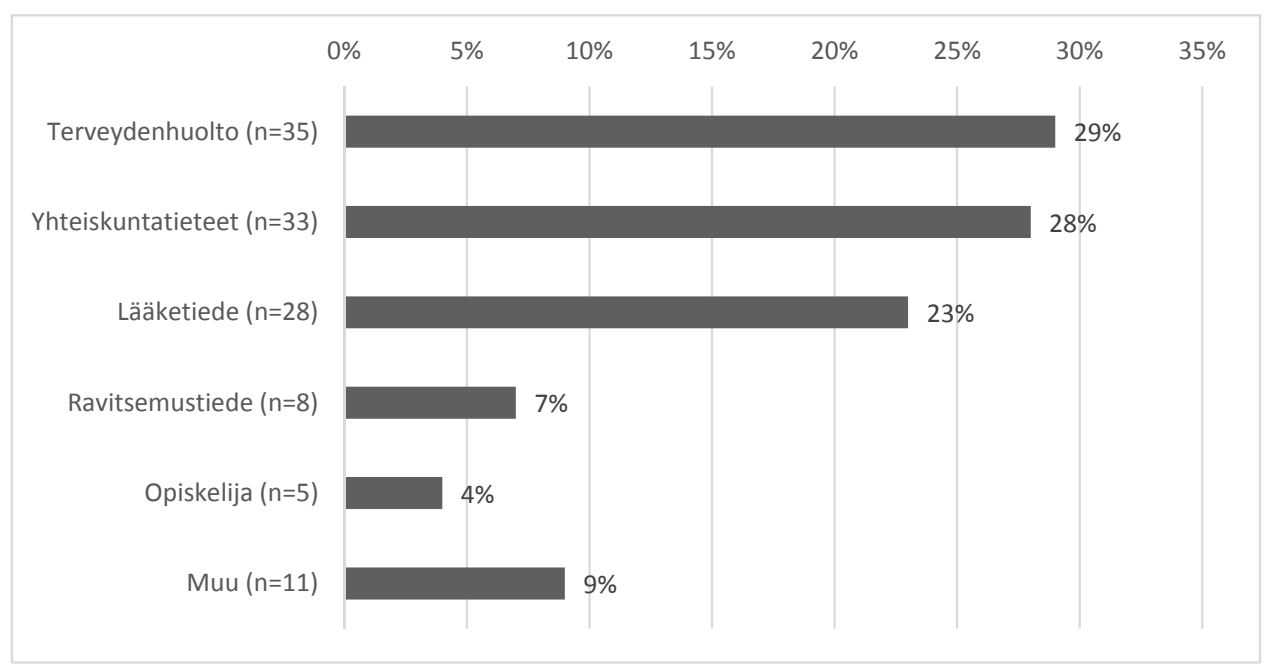

Kuvio 1. Vastaajien koulutusalat, mahdollista valita useampi vaihtoehto (vastaajia $n=104$, vastauksia $\mathrm{n}=120$ ).

Yhdistyksen tärkeimpiä toimintoja kartoitettiin monivalintakysymyksellä, jossa saattoi valita korkeintaan kolme vaihtoehtoa (kuvio 2). Sosiaalilääketieteellinen aikakauslehti on tärkeä toimintamuoto 29 prosentille vastaajista. Vastaajat kokivat tärkeiksi myös yhdistyksen järjestämät tapahtumat, kuten Sosiaalilääketieteen päivät $(18 \%)$ ja seminaarit $(14 \%)$, samoin kuin yhteiskunnalliseen keskusteluun osallistumisen $(17 \%)$. Jäsenten toiveita toiminnan lisäämiseen kartoitettiin vastaavanlaisella monivalintakysymyksellä: 32 prosentissa vastauksista toivottiin aktiivisempaa sosiaalilääketieteelliseen keskusteluun osallistumista ja seminaarien järjestämistä 23 prosentissa vastauksista. Yhdistyksen seminaaritapahtumien järjestelyihin, informatiivisuuteen, aiheisiin ja puhujiin oltiin avovastauksien perusteella pääsääntöisesti tyytyväisiä. Muutamassa avovastauksessa tuotiin esille korkeaksi koettu kynnys osallistua vuosikokouksiin ja paikkakunnasta riippuen myös seminaareihin. Esimerkiksi etäosallistumisen mahdollisuus parantaisi yhdistyksen toiminnan näkyvyyttä ympäri maan.

Yhdistyksen seitsemän jaoksen - käyttäytymislääketiede, lisääntymisterveys, lääketutkimus, mielenterveys, ruokatutkimus, terveydenhuoltotutkimus ja terveyssosiologia - toiminta ei monivalintakysymyksen perusteella ole tavoittanut vastaajia hyvin. Kysymykseen vastanneista $56 \%$ ilmoitti, ettei ole minkään jaoksen jäsen. Moni vastaajista tarkensi avovastauskentässä, etteivät joko tienneet jaosten toiminnasta mitään tai huomanneet omassa jaoksessaan aktiivista toimintaa. Toisaalta jaosten aktiivisuus vaihteli vastausten perusteella suuresti.

Yleistä tyytyväisyyttä yhdistyksen tiedottamiseen kartoitettiin Likert-asteikollisella kysymyksellä (asteikolla 1-5). Yhdistyksen tiedottamiseen oltiin tyytyväisiä. Vastaajista $69 \%$ oli tiedottamiseen tyytyväisiä tai erittäin tyytyväisiä. Neutraalin arvon 3 antoi $26 \%$ vastaajista. Erittäin epäonnistuneeksi viestintää ei arvioinut yksikään vastaaja, mutta noin $5 \%$ piti tiedottamista epäonnistuneena. Monivalintakysymyksessä kysyttiin, millä tavalla jäsen vastaanottaisi mieluiten yhdistyksen lähettämiä jäsentiedotteita. Ylivoimaisesti suurin osa eli noin $87 \%$ vastaajista toivoi jäsentiedotteita jatkossakin sähköpostitse.

Sosiaalilääketieteellinen aikakauslehti sai jäsenkyselyssä kiitosta (kuvio 3). Tyytyväisiä oltiin erityisesti painetun lehden saatavuuteen, sisältöön ja nimeen. Avoimessa palautekentässä toivottiin artikkelien sisältöjen monipuolisuutta ja laadullisten tutkimusmenetelmien erityispiirteiden huomioimista. Tulosten raportoinnin, käytettyjen menetelmien ja artikkelien yhdenmukaisuuden osalta kaivattiin tarkempaa vertaisarviointia ja toimitustyötä. Useampi vastaaja koki lehden artikkelit myös liian pitkiksi ja fokusoimattomiksi kaivaten tiivistämistä. Muutama vastaaja toivoi 


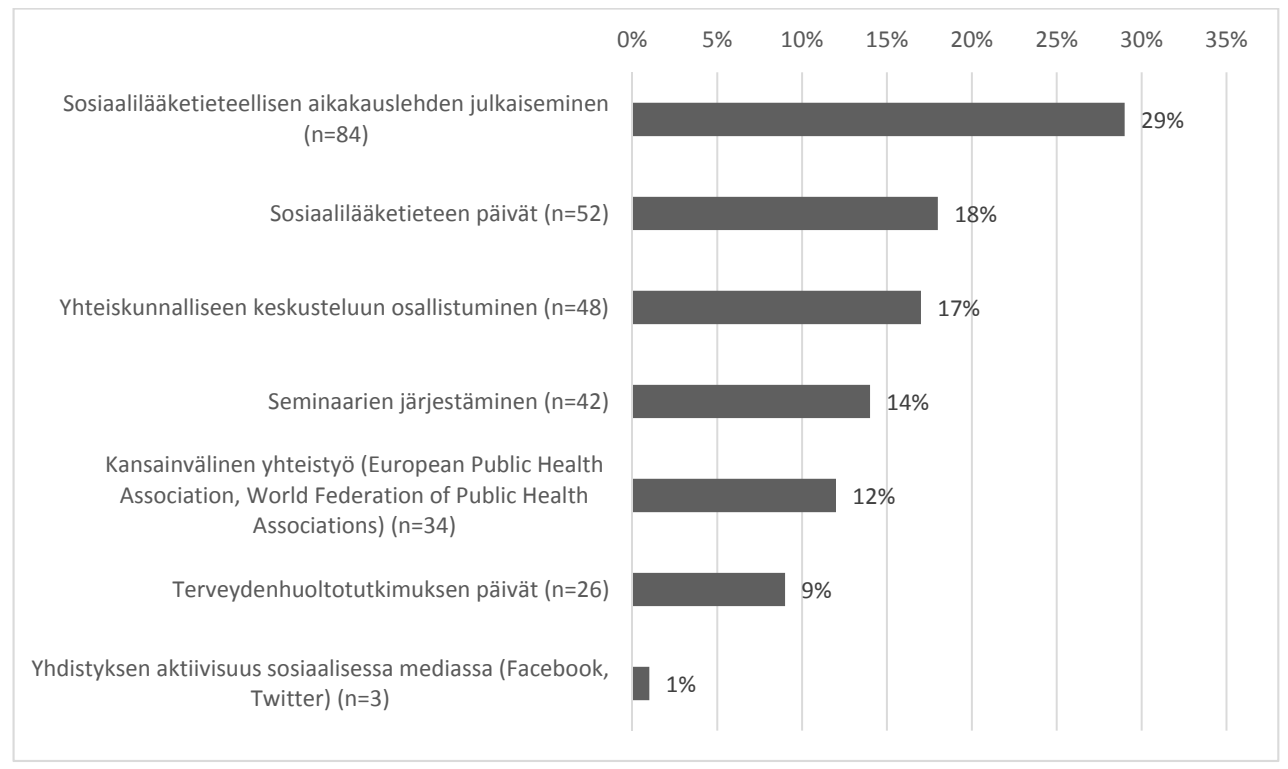

Kuvio 2. Yhdistyksen tärkeintä toimintaa jäsenten näkökulmasta, mahdollista valita korkeintaan kolme vaihtoehtoa (vastaajia $\mathrm{n}=104$, vastauksia $\mathrm{n}=289$ ).

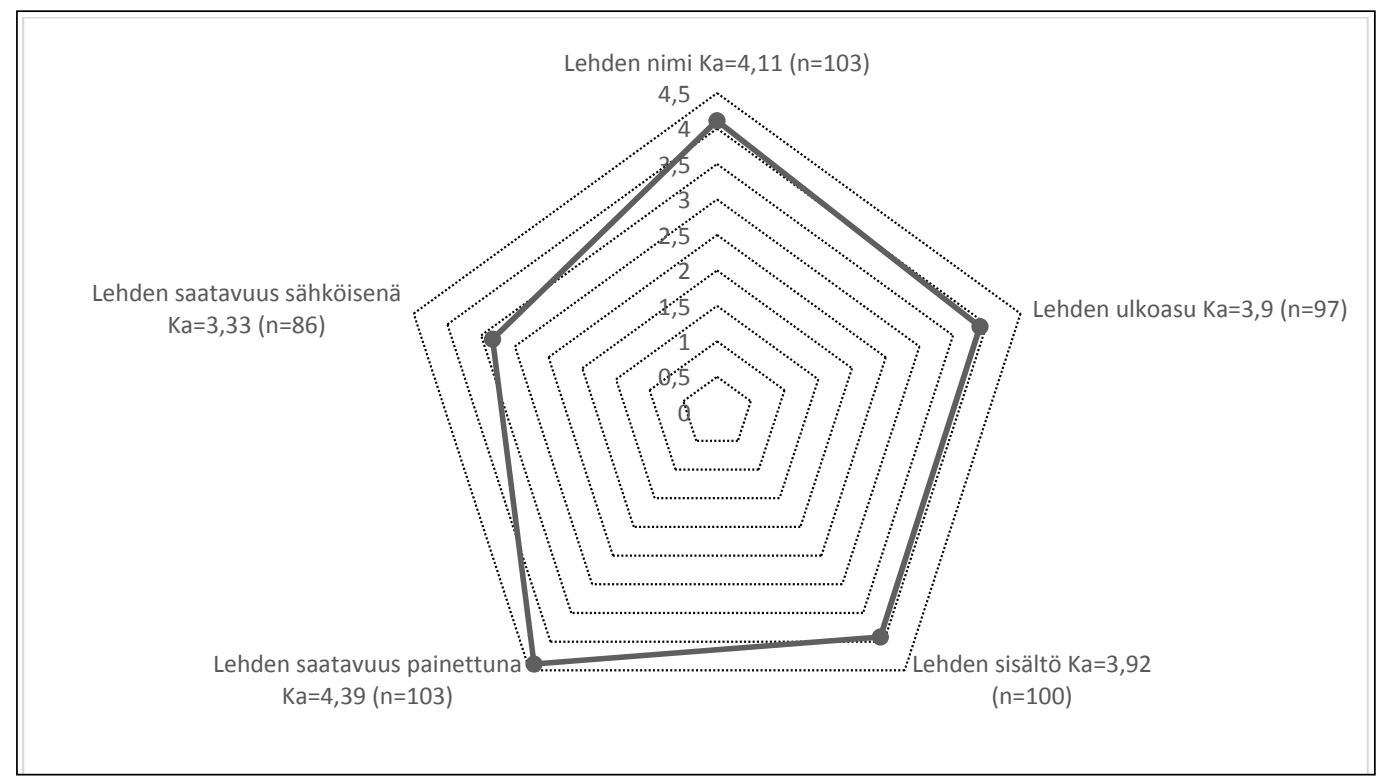

Kuvio 3. Vastaajien tyytyväisyys Sosiaalilääketieteellisen aikakauslehden eri osa-alueisiin, vastausten keskiarvot (Ka) asteikolla 1-5. Vastaajien lukumäärä (n) ilmoitettu kussakin kohdassa erikseen.

artikkelien herättävän enemmän keskustelua yhteiskunnallisesti ajankohtaisista ja puhutuista aiheista.

Kyselyssä pyydettiin yhdistyksen jäseniä kertomaan mielipiteensä myös lehden jakelusta: kuinka moni yhdistyksen jäsenistä säilyttäisi mieluiten nykyisen tavan (lehti toimitetaan pai- nettuna ja kuuden kuukauden julkaisuviiveen jälkeen lehden nettisivuilla) ja kuinka moni toivoisi lehden siirtymistä pelkästään sähköiseen julkaisuun. Suurin osa eli noin $74 \%$ vastasi pitäytyvänsä mieluiten nykyisessä tavassa. Neljäsosa vastaajista siirtyisi kokonaan sähköiseen lehteen. Kyselyssä selvitettiin myös yhdistyksen 
jäsenten näkemyksiä jäsenmaksun suuruudesta, jos julkaisutoiminta siirtyisi kokonaan sähköiseksi. Vastaajista $60 \%$ koki, että sähköiseen julkaisuun siirtymisen pitäisi pienentää jäsenmaksua. Jäsenmaksu on tällä hetkellä varsinaisilla jäsenillä 45 euroa ja opiskelijajäsenillä tai muilla työelämän ulkopuolella olevilla jäsenillä 20 euroa vuodessa. Jäseniltä kysyttiin myös euromääräistä arviota sopivan suuruisesta jäsenmaksusta. Vastausten keskiarvoiksi saatiin varsinaisilla jäsenillä 43,15 euroa (keskihajonta=7,10, vaihteluväli 18-60) ja opiskelijoilla 18,31 euroa (keskihajonta=5,21, vaihteluväli 0-30).

Vastaajat eivät olleet täysin tyytyväisiä sähköisen lehden saatavuuteen. Vajaat puolet vastaajista oli käyttänyt Sosiaalilääketieteellistä aikakauslehteä sähköisessä muodossa tai käynyt lehden Internet-sivuilla. Lehden Internet-sivujen käytettävyys Likert-asteikolla 1-5 sai kokonaisarvosanaksi keskiarvon 3,8. Kyselyn mukaan eniten tyytyväisiä oltiin Internet-sivujen selkeyteen (keskiarvo=3,91, keskihajonta $=0,69)$ ja sivujen ulkonäköön (keskiarvo=3,83, keskihajonta 0,62). Sähköisen lehden lukeminen sai kokonaiskeskiarvoksi 3,67 (keskihajonta 0,70). Edellä mainittuihin kysymyksiin liittyen kyselyssä oli avovastauskenttä, johon pystyi perustelemaan näkemyksiään sähköisestä lehdestä ja lehden Internet-sivuista. Avovastauksissa tuotiin esille se, että löydettävyys tietokannoista ja indeksointiin osallistuminen lisäisi lehden näkyvyyttä (taulukko 1). Uusimmasta sähköisestä lehdestä tiedottaminen esimerkiksi sähköpostin linkillä mahdollistaisi helpon lukemisen myös vaikkapa mobiililaitteilla. Vain $8 \%$ vastaajista ilmoitti käyttäneensä Journal.fi-palvelua artikkelikäsikirjoitusten lähettämiseen lehdelle, joten palvelun toiminnasta ei saatu riittävästi vastauksia tarkempaa analyysiä varten.

Taulukko 1. Lehden vaikuttavuuden ja näkyvyyden lisääminen jäsenten ehdotusten mukaisesti.

\begin{tabular}{ll}
\hline $\begin{array}{l}\text { Markkinointi ja } \\
\text { näkyvyys }\end{array}$ & $\begin{array}{l}\text { Yhdistyksen ilmeen uudistaminen } \\
\text { mahdollisuus jakaa artikkeleita sosiaalisessa } \\
\text { mediassa ja keskustella niistä }\end{array}$ \\
\cline { 2 - 3 } & Avoin saatavuus (opetukseen), indeksointi \\
\hline $\begin{array}{l}\text { Kannanotot yhdistyksen aktiivisesta } \\
\text { elimestä, yhdistyksen edustaminen } \\
\text { yhdistyksen ulkopuolisissa tilaisuuksissa }\end{array}$ & $\begin{array}{l}\text { Yhteistyö maalikkojulkaisujen ja tiedejulkaisujen } \\
\text { kanssa }\end{array}$ \\
\hline & $\begin{array}{l}\text { Mainostus sosiaalisessa mediassa, mediatiedotteet, markkinointi kuntien } \\
\text { tiedottajille, maakuntakirjastoille ja opiskelijoille, lääkäreille jaettavat } \\
\text { teemanumerot }\end{array}$
\end{tabular}

Lehden sisällöt

Vapaamuotoisemmat tekstit ja kannanotot, ajankohtaiset aiheet

Tiiviimmät ja fokusoidummat artikkelit

Poikkitieteellisyys (esim. terveyspolitiikka, oikeustiede...), lisäksi lääketieteellisen näkökulman säilyttäminen

Laadullisten tutkimusten lisääminen ja laadullisten

tutkimusmenetelmien ominaispiirteiden huomoiminen -> esimerkiksi

sanamäärä nykyisissä artikkeleissa riittämätön 


\section{LOPUKSI}

Väitöskirjaansa varten vuonna 1999 tekemässään kyselyssä Ranja Aukee (2013) selvitti Sosiaalilääketieteen yhdistyksen jäsenten toiveita koskien yhdistyksen toimintaa (1). Samoin kuin tässä lähes 20 vuoden takaisessa jäsenkyselyssä, yhdistyksen jäsenet pitävät edelleen arvossaan yhdistyksen yhteiskuntaa ja terveydenhuoltoa yhdistävää tematiikkaa ja peräänkuuluttavat yhteiskunnalliseen keskusteluun osallistumista.

Muutamissa avovastauksissa toivottiin, että jatkossakin yhdistyksellä ilmestyy lehti, joka painettuna julkaisuna sopii kahvipöytään. Tämä ei välttämättä tarkoita sitä, etteikö esimerkiksi myös mobiililaitteilla olisi sijaa samassa pöydässä. Siksi sähköisen lehden helppokäyttöisyyden ja luettavuuden kehittämistä koskevat jäsenten näkemykset ovat yhdistykselle tärkeitä. Yhdistyksen kyselyssä keräämä palaute osoitti paitsi jäsenten tyytyväisyyden toimintaan monilla eri osa-alueilla, myös lehden aseman yhdistyksen toiminnan keskiössä. Vastaajat toivoivat yhdistykselle ja lehden toimitukselle suunnatuissa avovastauksissaan uusien teknologioiden ja kansainvälisen informaation hyödyntämistä lehdessä ja yhdistyksen toiminnassa, ja nuorten tieteentekijöiden huomioimista osana tulevaisuuden tieteellistä kenttää. Lisäksi sekä lääketieteellisen että yhteiskunnallisen näkökulman yhdistäminen näh- tiin edelleen tärkeäksi julkaisussa ja seminaarien teemoissa.

Kyselyllä kerättyjä näkemyksiä käytetään yhdistyksen ja lehden toiminnan kehittämiseen. Yhdistys tarvitsee aktiivisia jäseniään ollakseen olemassa myös seuraavat 50 vuotta, joten kaikki jäsenistön mielipiteet ovat yhdistykselle arvokkaita.

Kiitämme kyselyyn osallistuneita jäseniämme!

\section{LÄHTEET}

(1) Aukee R. Vanhasta uuteen sosiaalilääketieteeseen: Suomalaisen sosiaalilääketieteen muotoutuminen 1800-luvun lopulta vuosituhannen vaihteeseen. Väitöskirja, Tampereen yliopisto; 2013.

\section{LAURA Pä̈̈KKÖ}

Opiskelija

Tampereen yliopisto

Peija HaAramo

FT, VTM, tilastotutkija

Terveyden ja hyvinvoinnin laitos

Kansanterveysratkaisut-osasto

Mika Gissler

FT, VTM, tutkimusprofessori

Terveyden ja hyvinvoinnin laitos

Tietopalvelut-osasto

Karoliininen instituutti 